\title{
Economic and Political Diplomacy in Disruption Era Through Indonesian for Speakers of Other Language (BIPA) Teacher Assignment Overseas
}

\author{
Eko Widianto ${ }^{1}$, Sofi Aulia Rahmania ${ }^{2}$ \\ ${ }^{1}$ Department of Indonesian Language and Literature Education, Universitas Muria Kudus \\ ${ }^{2}$ Teacher of Indonesian for Speakers of Other Language (APPBIPA) Central Java \\ ${ }^{1}$ Corresponding email: eko.widianto@umk.ac.id
}

\begin{abstract}
This study represented about the benefit of learning of Indonesian for Speakers of Other Language (BIPA) in disruption era, particularly for Indonesian economic and politics. However, one of the purposes of BIPA Learning was diplomacy such as cultural, tourism, or political diplomacy. Thus, Indonesian for Speakers of Other Language (BIPA) learning could be used as a way to introduce Indonesian economic and politics dimensions. This study used qualitative descriptive methodology approach. The data were collected via observation method and other advanced techniques. There were many interesting results from this research i.e. 1) how to deal an economic diplomacy in disruption era through BIPA Learning; 2) how to deal a political diplomacy in disruption era through BIPA Learning; 3) teacher's strategy of diplomacy in the overseas to increase Indonesian economic and politics; and 4) the advantages of BIPA teacher assignment to the overseas in disruption era. This study argue that BIPA had a great chance to increase and improve Indonesia's diplomacy quality. BIPA teacher assignment to the overseas also gave a big benefit for Indonesian economy, politics, culture, tourism, etc. However, BIPA Learning became a cultural diplomacy process among Indonesia and other countries in the world.
\end{abstract}

Keywords: BIPA, Indonesian for Speakers of Other Language, Economic and Political Diplomacy, Disruption Era

\section{Introduction}

The assignment of BIPA teachers to abroad is not only aimed of teaching language and Indonesian culture but also to deliver economic and political diplomacy. One of the most important forms of political diplomacy is upholding itself to participate in maintaining world peace, as it is known that Indonesia has an active free foreign policy and Pancasila democracy politics. BIPA teachers can disseminate peace through language teaching. Because, there are cultural and multicultural elements in language teaching that promote togetherness in diversity (Wurianto 2016, Suhardijanto 2016, and Widianto 2017).

In addition, in the economic sector, Indonesia needs to open the widest market in the world where in the era of industrial revolution 4.0 (disruption) is the era of world economic explosion as big as possible. If Indonesia only roads in the country alone, Indonesia will not experience economic improvement. Therefore, one of the important goals of the assignment of BIPA teachers is declare a populist economy in the international arena. Indonesia's creative industries should be introduced internationally through the teaching of BIPA (Kusmiatun 2015 and Widianto 2016).
The assignment of BIPA teachers must have a good essence, which has the essence of disseminating or deciphering politics and economics. The ultimate essence of BIPA's teaching is not on language teaching and cultural recognition, but language and culture are the advocates of political missions and economic missions in the international arena. In this paper, will be discussed the forms of political and economic diplomacy through the assignment of BIPA teachers abroad in the era of disrupsi.

\section{Methods}

This research method used descriptive qualitative method by describing the forms of political and economic diplomacy in the era of disrupsi through the assignment of BIPA teachers abroad. In addition, also used method of autoetnography. The method of auto ethnography is to examine what researchers do when assigned to BIPA teachers abroad and to implement language and cultural diplomacy that leads to political and economic diplomacy.

\section{Result \& Discussion}

The paper is based on the researcher's experience when assigned to be a BIPA lecturer 
in Tunisia who has conducted economic and political diplomacy.

There are several forms of economic diplomacy. First, the form of economic diplomacy conducted in the classroom. Second, economic diplomacy by providing motivation or offer to BIPA learners.

The form of diplomacy conducted in the classroom is that BIPA teachers can choose learning materials around the economic topics residing in Indonesia. One of the economic topics that can be used as learning materials BIPA is the topic of tourism. Tourism topics are the most popular topic of BIPA learners, such as nature tourism, culture, and religion. These topics can be a learner attraction to come to Indonesia. If the tourism sector increases, then the economic sector will also increase.

One of the tourism sector that became a prima donna is nature tourism. Indonesia has a natural beauty that has been recognized by the world, such as the beach that stretches from Sabang to Merauke. In addition, Indonesia also has a mountain range in which there are forest tours, rivers and waterfalls are beautiful. Another tourism sector that can be offered is cultural tourism. Indonesia has a variety of historical relics, such as temples scattered across the archipelago and art that is a form of Indonesian society culture.

Other tourism that can be offered is religious tourism. Although the population of Indonesia is predominantly Muslim, not only traces of Islamic relics are many. Other religions also have many traces of relics, such as traces of Christian and Catholic relics in the towns of Salatiga and the city of Manado, traces of Buddhist heritage, such as Borobudur temple in Magelang city, and traces of Hindu religious heritage scattered on the island of Bali. The traces of Confucian religious heritage in the city of Semarang is Sam Poo Kong.

In addition to the tourism sector, the potential of Indonesian culinary can also be the attraction of BIPA learners. Indonesia is rich in culinary archipelago that has a variety of flavors. Culinary-culinary originating from Indonesia can be introduced through BIPA class in several ways. Besides being used as learning materials, BIPA teachers can make the topic as cooking demonstration material. BIPA learners can learn how to cook Indonesian food. After learning how to cook Indonesian food, BIPA learners can practice and the results can be exhibited. Thus, not only BIPA learners in those classes who can feel the culinary Indonesia, but all the people who are in the environment BIPA learners can also feel the culinary Indonesia. For example, BIPA teachers organize cultural and culinary festivals in Indonesia that are held in a university. Not only BIPA learners in that class alone who know the culture of Indonesia and can feel the culinary of Indonesia, but the entire academic community at the university can feel.

Economic diplomacy can also be done through the craft sector. BIPA learners are introduced to Indonesian crafts, such as batik, weaving, wayang, traditional musical instruments, and so forth. The craft can be introduced in several ways. In addition to serve as learning materials, teachers and learners of BIPA can practice how to make crafts typical of Indonesia. After the learners practice making crafts typical of Indonesia, the results can be exhibited so as to increase the attractiveness of people who are in the environment around BIPA learners.

The second way to conduct economic diplomacy is to provide motivation or offer to BIPA learners. There are two motivations or offers that can be given to BIPA learners. First, the motivation or offer to come to Indonesia. Second, to open an Indonesian culinary business in the country. If in the country there is no restaurant that sells Indonesian culinary, then it can be a business opportunity for BIPA learners, such as Indonesian people who sell Japanese and Korean culinary in Indonesia. If BIPA learners are not ready to open their own culinary business, give them an offer to work with Indonesians. It can provide opportunities for young entrepreneurs in Indonesia to open a culinary business Indonesia abroad.

This is the reason why Indonesian culinary should be introduced in BIPA class first so that BIPA learners and people in BIPA learning environment do not feel foreign and accept culinary Indonesia. In addition, the purpose of Indonesian culinary introduction is to see the market response because BIPA class is an economic sample in the destination country, such as the type of food suitable for sale in the destination country. Based on the experience of researchers at BIPA in Tunisia, researchers have introduced several types of Indonesian food to BIPA learners at the University of Sousse, such as coffee, cakes, resoles, pukis, and lumpia. It turns out that BIPA learners are very fond of coffee. From that experience, if cakes, resoles, or pukis were sold in Tunisia, then the food 
would not be sold and only coffee would be sold in Tunisia. Based on the experience, the next follow-up is the lecturer BIPA tells the staff of the Embassy in Tunisia related to the economy. Finally, the staff gave Indonesian youth opportunities to open cafes in Tunisia although initially only in the exhibitions that developed into cafes. That is the first cafe inspired by BIPA Tunisia.

\subsection{A Form of Political Diplomacy}

Indonesia has a political system exemplary by other countries. Indonesia is a country that has a diversity of tribes, religions, races and languages that coexist in the midst of civil society. The political view of Indonesian society is much more open than the people of other countries because Indonesian society is more democratic and stronger togetherness. This political view needs to be introduced to the world that Indonesia is the most peaceful country and most ready to accept diversity and diversity, especially for BIPA learners. It can be introduced through BIPA learning materials. In addition, the length of Indonesian history can also be told to BIPA learners. It is not the history of Indonesia colonized for years told, but the history of the struggle and the persistence of the Indonesian people against the people who do not deserve to stand in Indonesia.

Based on the experience of researchers in Tunisia, materials such as democracy and Indonesian history are in great demand so specifically at the University of Sousse there is a special class of learning history of Indonesia. The materials raised in the learning are materials related to politics and democracy, such as the development of Indonesian independence, the era of reform, the forms of Indonesian democracy, the form of Indonesian government, and so forth. It is interested BIPA learners in Tunisia because they want to learn democracy.

If traced in terms of history, Indonesia and Tunisia have a historical equation, which was once led by a president in a long time. Tunisia and Indonesia both uprooted the tyranny. However, Indonesia's surplus after the dictatorial era that collapsed was that Indonesia immediately built an era of reform and did not linger in the failure of democracy. This is what attracted BIPA learners.

Another interesting political view is the spread of Islam in Indonesia. In the past, the entry of Islam in Indonesia was not by violence. It is certainly different from other countries through war. This is because in Indonesia there is a songo wali who spread the religion of Islam using the elements of culture. Sunan Bonang teaches Islam with bonang. Bonang is one of Javanese traditional musical instruments, usually called gamelan. Sunan Kalijaga spread Islam using the wayang kulit art. In this way, slowly the Indonesian people enter Islam sincerely without any war and divisions. It is an example that Indonesian politics was born with a cool and born with ayem. This is the attraction and value of teaching BIPA, especially in Islamic countries, such as Tunisia.

\subsection{The Benefits of Economic and Political Diplomacy through the Assignment of BIPA Teachers to Abroad}

Economic and political diplomacy in the disruption era through the assignment of BIPA teachers abroad this certainly has benefits for Indonesia. The first benefit is to improve Indonesia's economy through several sectors that have been described in the previous paragraph. Second, confirms Indonesia's identity in the international arena. Indonesia is ready to become an economic player in the international arena in a way that is different from other countries. If other countries use advanced technology, Indonesia uses other channels, namely language and cultural learning paths. Third, affirming the Indonesian political view that from the first to the present political views of Indonesia remain a political view that promotes peace. The political view that considers diversity is a gift of God Almighty and diversity not for division, but for togetherness.

\section{Conclusion}

The sending of BIPA teachers abroad to this disruption is a good and absolute thing to continue because through the delivery of economic diplomacy and polity will continue to grow. This is one way to follow the era of industrial revolution. If other countries use the power of technology to improve their economies, Indonesia has another way of growing politics and economy through the cultural sector.

\section{References}

Kusmiatun, Ari. 2015. Mengenal BIPA (Bahasa Indonesia Bagi Penutur Asing) dan Pembelajarannya. Yogyakarta: K-Media.

Suhardijanto, Totok. 2016. "Tantangan dan Peluang Pengembangan BIPA di Masa 
Mendatang: Penguatan Dimensi-Dimensi BIPA". Prosiding SEMAR BIPA 2016. Universitas Negeri Semarang. Volume I. Hal. 10-17.

Widianto, Eko. 2016. "Pilihan Bahasa dalam Interaksi Pembelajaran Bahasa Indonesia bagi Penutur Asing". Seloka: Jurnal Pendidikan Bahasa dan Sastra Indonesia. Universitas Negeri Semarang. Volume 5 nomor 2. Hal. 124-135.
Widianto, Eko. 2017. "Media Wayang Mini dalam Pembelajaran Keterampilan Berbicara bagi Pemelajar BIPA A1 Universitas Ezzitouna Tunisia". KREDO: Jurnal Ilmiah Bahasa dan Sastra. Volume 1 nomor 1. Hal. 120-143.

Wurianto, Arif Budi. 2016. "Pengembangan dan Pembelajaran BIPA Berbasis Lintas Budaya". Prosiding SEMAR BIPA 2016. Universitas Negeri Semarang. Volume I. Hal. 18-25. 